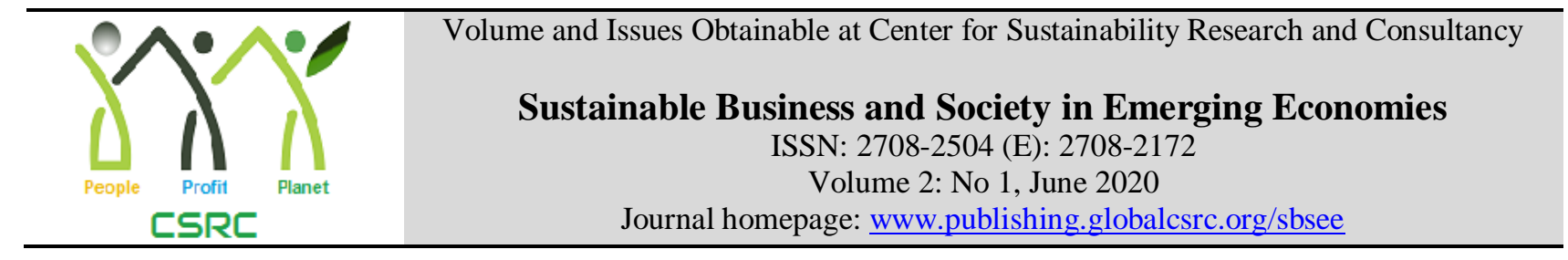

\title{
Effect of Corporate Governance and Capital Structure on Corporate Performance in Malaysian Listed Companies: A Conceptual Approach
}

\author{
${ }^{1}$ Fauzan, ${ }^{2}$ Azhar Bin Abdul Rahman, ${ }^{3}$ Marhaiza Binti Ibrahim \\ ${ }^{1} \mathrm{PhD}$ Scholar, Department of Tunku Puteri Intan Safinaz School of Accountancy, Universiti Utara Malaysia, \\ fauzansholeh76@gmail.com \\ ${ }^{2}$ Professor, Department of Tunku Puteri Intan Safinaz School of Accountancy, Universiti Utara Malaysia, \\ azhar258@uum.edu.my \\ ${ }^{3}$ Senior Lecturer, Department of Tunku Puteri Intan Safinaz School of Accountancy, Universiti Utara Malaysia, \\ marhaiza@uum.edu.my
}

\begin{tabular}{ll}
\hline \multicolumn{1}{c}{ ARTICLE DETAILS } & ABSTRACT \\
\hline $\begin{array}{l}\text { History } \\
\text { Revised format: May } 2020\end{array}$ & $\begin{array}{l}\text { Purpose: Corporate governance and capital structure are seen as significant } \\
\text { fvailable Online: June } 2020\end{array}$ \\
& $\begin{array}{l}\text { factors in improving corporate performance. Many researches focusing on } \\
\text { conducted. However, the information involving public firms in Malaysia }\end{array}$ \\
\hline Keywords & remains scarce. Hence, this research aims to advance a conceptual framework \\
Corporate Governance, Capital & that perceive the two major factors; corporate governance and capital \\
Structure, Corporate Performance, & structure, towards the performance of public firms in Malaysia. \\
Malaysia & Design/Methodology/Approach: The annual reports of the companies \\
\hline JEL Classification: & registered in Bursa Malaysia (year 2013 to 2016) was used as the secondary \\
L26, L31 & data. The data was extracted using Thomson Reuters Data Stream Version 5.1 \\
& which available at the Sultanah Bahiyah Library of Universiti Utara Malaysia. \\
& Implications/Originality/Value: The information provided in this study will \\
& serve as an added knowledge to redefine the corporate governance policy and \\
& capital structure towards strengthening the role of corporate governance and \\
& capital structure in public firms in Malaysia This research will facilitate \\
further enhancement of the company performances and benefit the financial \\
report users, creditors, investors, shareholders, as well as stakeholders in \\
public firms in this country.
\end{tabular}

\section{OPEN ACCESS}

(C) 2020 The authors, under a Creative Commons Attribution-

NonCommercial 4.0

Corresponding author's email address: fauzansholeh76@gmail.com

Recommended citation: Fauzan, Rahman, A. B. A., \& Ibrahim, M. B. (2020). Effect of Corporate Governance and Capital Structure on Corporate Performance in Malaysian Listed Companies: A Conceptual Approach. Sustainable Business and Society in Emerging Economies, 2(1), 37-46

\section{Introduction}

Corporate performance has always been a major concern among the stakeholders within a company, including the proprietor, investor, supplier as well as the employee (Jaffar \& Abdul-Shukor, 2016; Madrid-Guijarro et al., 2007; Omnamasivaya \& Prasad, 2017; Patel et al., 2015; Sinesilassie et al., 2017). According to the researchers, a solid company performance will allow the company to produce trade opportunities and increase prosperity. Truncated 
performing companies are commonly not competitive and more likely to experience financial difficulties (Brigham \& Houston, 2014). Therefore, it is important for a company to review their performance over the period in stripe with constant changes in the commercial situation (Najmi et al., 2005).

Performance dimension will inform companies to income appropriate achievement and change their strategy to secure the company's upcoming (Najmi et al., 2005). Parker (2000) highlighted numerous reasons urging the needs of an organization to quantify their performance. These include to evaluate the achievement of the company, to determine whether there is an increase in profit, to understand the process of all activities occurring within the company, to recognize where problems may ascend and actions to be taken to correct them, to meet customer needs and to ensure that decisions are made according to a proper evaluation.

Corporate governance has been reported to give influence on the performance of a company (Abidin et al., 2009; Ahmed Haji, 2014; Akpan \& Amran, 2014; Al-Ghamdi \& Rhodes, 2015; Apadore \& Zainol, 2014; Bahreini \& Zain, 2013; Ghazali, 2010; Haniffa \& Hudaib, 2006; Johl et al., 2015; Ong et al., 2015), capital structure (Ali et al., 2016; Ana et al., 2012; Basit \& Hassan, 2017; Bhattarai, 2016; Goyal, 2013; Salim \& Yadav, 2012; San \& Heng, 2011; Tharmila \& Arulvel, 2013; Vătavu, 2015; Zeitun \& Tian, 2007). Corporate governance is an established instrument that is adopted to ensure that directors and managers make decisions and operate the company in a way that benefits the stakeholders (Lashgari, 2004). This mechanism includes the procedures, duties, rules, regulations and organizations that affect the way companies are governed, directed, or measured. The Malaysian Code on Corporate Governance (MCCG) 2017 (Mustapha \& Ahmad, 2011) stating that the corporate governance is a term that is regularly used to describe procedures and constructions in directing and managing corporate business activities to enhance shareholder productivity.

Corporate governance is a major pillar for an organization in emerging its goals (Hermalin, 2005), particularly in terms of financial disclosure. Current corporate governance is related to higher quality of monetary discovery. Accordingly, MCCG also encourages municipal corporations to adopt good governance observer practices (AhmadZaluki \& Wan-Hussin, 2010).

Taking the lesson from the corporate failures and the accounting (scandals) such as that happened to Enron in 2001, MCI WorldCom in 2002, Xerox in 2002, Tyco in 2002, Parmalat in 2003, Lehman Brothers (2008) and Satyam (2009) emphasizing the importance to create better governance for all countries.

In Malaysia, the corporate background has been sparked by several cases of corporate governance that have a poor record of history such as Renong in 1997 that made loans and had to incur the debt of RM 20 billion (Malaysia Today, 2010). In addition, the Malaysia Airlines System (MAS) in 1999 suffered losses of RM 260 million, while Perwaja Steel in 2004 suffered losses of RM 2.56 billion (Utaranews, 2017). Transmile in 2007 and the Klang Free Zone (PKFZ) in 2009 also suffered losses of RM 227 million and RM 254.85 million, respectively (Malaysia Kini, 2016).

In addition to the trust cases, the Minority Shareholder Watchdog Group (KPPSM / MSWG) in 2017 released statistical data on corporate governance obtained from the publicly listed companies on Bursa Malaysia. Based on these statistical data, corporate governance in Malaysia seems to continue to decline and increase (MSWG, 2017).

As such, the Malaysian administration has reserved steps to evaluate and support the corporate governance wherein 1998, the Malaysian Institute of Corporate Governance (MICG) was set up to develop corporate governance in Malaysia. One of its main responsibilities is to develop better practice guidelines by taking examples from companies in other developed countries around the world.

Besides, another factor that causes fluctuations in a company's performance is the capital structure. Capital structure is the approach taken by a company to finance its sources of investment (assets) through the proportions of liability and impartiality (Saad, 2010). Brockington (1990) and Ahmadpour \& Yahyazadehfar (2010) describes the capital structure as a component of financing sources consisting of equity and debt.

Generally, companies can choose different types of capital structure. Based on the financial theory, capital structure is 
said to affect the financing of a firm and its economic presentation (Abor, 2005). It also influences the commercial activity of a company since it involves the managements of financial resources that available to conduct commercial activities.

The breather of the paper is organized as surveys. The following discussion will include the summary of the previous researches that focusing on the hypothetical background of the association between the corporate governance and the corporate performance as well as the corresponding hypotheses that have been developed in this study.

\section{Literature Review}

An overview of the literature related to the topics under review is corporate performance, corporate governance, and capital structure.

\subsection{Corporate Performance}

The corporate performance is assessed by its achievement or the marketplace situation (Hooley et al., 2001). According to Abu-Jarad et al., (2010) most educations have created that dissimilar firms in dissimilar states incline to provide dissimilar presentation evaluation criteria. Several publications have suggested the monetary productivity and development of the company as the greatest commonly used criteria for evaluating corporate performance.

Several scholars take trusted on particular presentation criteria for a company such as creation achievement, sales and marketplace part development, and productivity associated to their projections (Maury, 2006). Other researchers use impartial presentation criteria in relations of revenue, efficiency, distribute sales, productivity, maintenance efficiency, timely delivery, volume consumption, and value (Lind et al., 2000). The use of such objective performance standards is the simplest way to evaluate a company's presentation. Corporate performance also remains restrained by means of long-term criteria such as market presentation and short-term criteria such as a non-market presentation. Some examples of the standards that can be used are the market value addition (MVA), economic value addition (EVA), cash flow growth, earnings per share (EPS), asset growth, dividend growth, and sales growth (Abdullah, 2004; Coles et al., 2001).

However, this research will use returns on assets (ROA) and returns on equity (ROE) as indicators to assess company performance. This method was adopted in the previous study by Dehaene et al., (2001) in their research regarding the firms in Belgium and several other studies such done by Haniffa \& Hudaib, (2006) and Aik Leng \& Abu Mansor, (2005). Brown and Caylor (2005) also used ROA and ROE as key measures in assessing the corporate presentation. The data of the profit before interest and tax were used as it reflects the company's actual performance and acts as a dependent variable. Additionally, this research will also use the Tobin Q and Intellectual Capital Value Added to measure the company performance.

\subsection{Corporate Governance}

Corporate governance could be described as the process of how the organization is operated. This process requires stability among the responsibilities of the numerous stakeholders to achieve the financial purposes of the association (Bonn \& Fisher, 2005). Corporate governance involves the use of systems or instruments that guides the company management to a decision making that will benefits its stakeholders (Denis \& McConnell, 2003). Corporate governance is mainly developed to observe the behaviour of diverse stakeholders and to decrease the agency costs related to principal and agent relationships (Lashgari, 2004; Runhui et al., 2011; Xu \& Qiu, 2012). Arora and Sharma (2016) studied the companies of the 20 most important industries in India. They found out that large board size tends to give an advantage to the board of directors, especially to the decision-makers, and consequently affect the financial performance of a company. However, Arora and Sharma (2016) reported that quality does not show a significant part in the presentation of the company, especially on ROE.

The researches that studied on the influence of corporate governance towards the performance of companies in Malaysia has not produced any conclusive results. Ghazali (2010) in his research of 87 non-financial companies listed under the composite index in Malaysia reported that the company performance was not significantly affected by its corporate governance. Abidin et al., (2009) in their research of 75 firms revealed that the importance of the independent directors that was highlighted by the MCCG $(2011,2012)$ and Bursa Malaysia is strongly related to the company performance in a long period of time. Meanwhile, a research conducted by Haat et al., (2008) involving 142 
firms in Malaysia concluded that corporate governance serves a robust impact on predicting a firm performance. Ponnu (2008) in his research of 100 Bursa Malaysia companies stated that there was a strong association between the corporate governance structure and the corporate presentation.

Koufopoulos et al., (2008) that studied on 27 companies listed under the Athens Stock Exchange (ASE) reported that the only factor that produce a positive impact on the company performance is the board size. However, the impact is not statistically significant. Uadiale (2010) that studied 30 companies listed under Nigeria Stock Exchange (NSE) found a negative relationship between the ROE castoff as a representation to assess the presentation of the firm by the quality functions of the chairman and chief executive officer. On the other hand, Sanda et al., (2005) found a positive association between the company performance and the segregation of the duty and function of chief executive and chairman in 93 companies under NSE. However, Leng and Mansor (2005) that studied the 120 registered corporations in Malaysia over four years (1996 to 1999) found that the chief executive with the chairmanship of the board of directors influenced the company performance positively.

\subsection{Capital Structure}

Capital structure could be defined as the proportion of sanctuaries used by a company for the purpose of a long-term financing and debt. These include the external equity, internal equity, and major stocks (Margaritis \& Psillaki, 2010). The ordinary share capital is commonly obtained form the public through the issue of ordinary shares to the shareholders. This type of finance is only applicable to certain type of companies. These shares provide voting rights and may affect the company's decision-making process at the Annual General Meeting. The common stock comes with the high level of risks due to the uncertainty of the refund. Ordinary stocks cannot guarantee refunds and have outstanding claims.

In corporate finance, capital structure is a term used to describe the way a company manage its assets by balancing the ratio of debt, equity or hybrid securities (Saad, 2010). It describes how a company use its entire procedures and development using various bases of resources.

Modigliani-Miller theory is the most adopted theory of capital structure and has been widely accepted around the world. According to Modigliani-Miller, this capital structure operates in a perfect market. Numerous perfect market norms have been made up of rational investment uses, no taxation, perfect competition, no bankruptcy and efficient markets. Modigliani-Miller stated that the financial or financial structure of a company is not associated with the value of a perfect market.

Gleason et al., (2000) reported that different capital structures and classification of retail culture will affect the structure of retail capital. The study that was conducted on 14 European countries revealed that the culture does not influence the retailer presentation and the capital structure have influence on the company performance.

On the other hand, another research was carried out by Akintoye (2008) to understand the capital structure presentation for the selected food and beverage firms in Nigeria. This research used sales as an indicator of company performance and leverage as an indicator for the fashion structure. Akintoye (2008) concluded that capital structure significantly affects company performance.

King \& Santor (2008) studied the connection between family ownership, corporate performance and capital structure of companies in Canada. Based on Tobin Q's ratios, the results show that families with independent companies having a single class of shares shows the same marketplace presentation, higher bookkeeping presentation constructed on ROA, and higher financial leverage based on overall debt to other assets compared to other companies. By comparison, family-owned companies having two-class shares shows a lower valuation of up to $17 \%$ relative to the company size, despite having the same ROA and financial leverage.

In the present study, we used short-term liability, long-term liability and total liability as a measure for capital structure. 


\section{The Conceptual Framework and Hypotheses Development}

The conceptual framework was designed to discover the association between corporate governance and capital structure with corporate performance. In this proposed framework, corporate governance (including the independent directors, CEO duality, board size, board meetings, shareholder ownership, and tenureship) and capital structure (including short-term liability, long-term liability, and total liability) was considered as independent variables and the performance of the company was set as the dependent variable. Figure 1 shows the association between corporate governance and corporate performance as well as the relationship between capital structure and corporate performance.

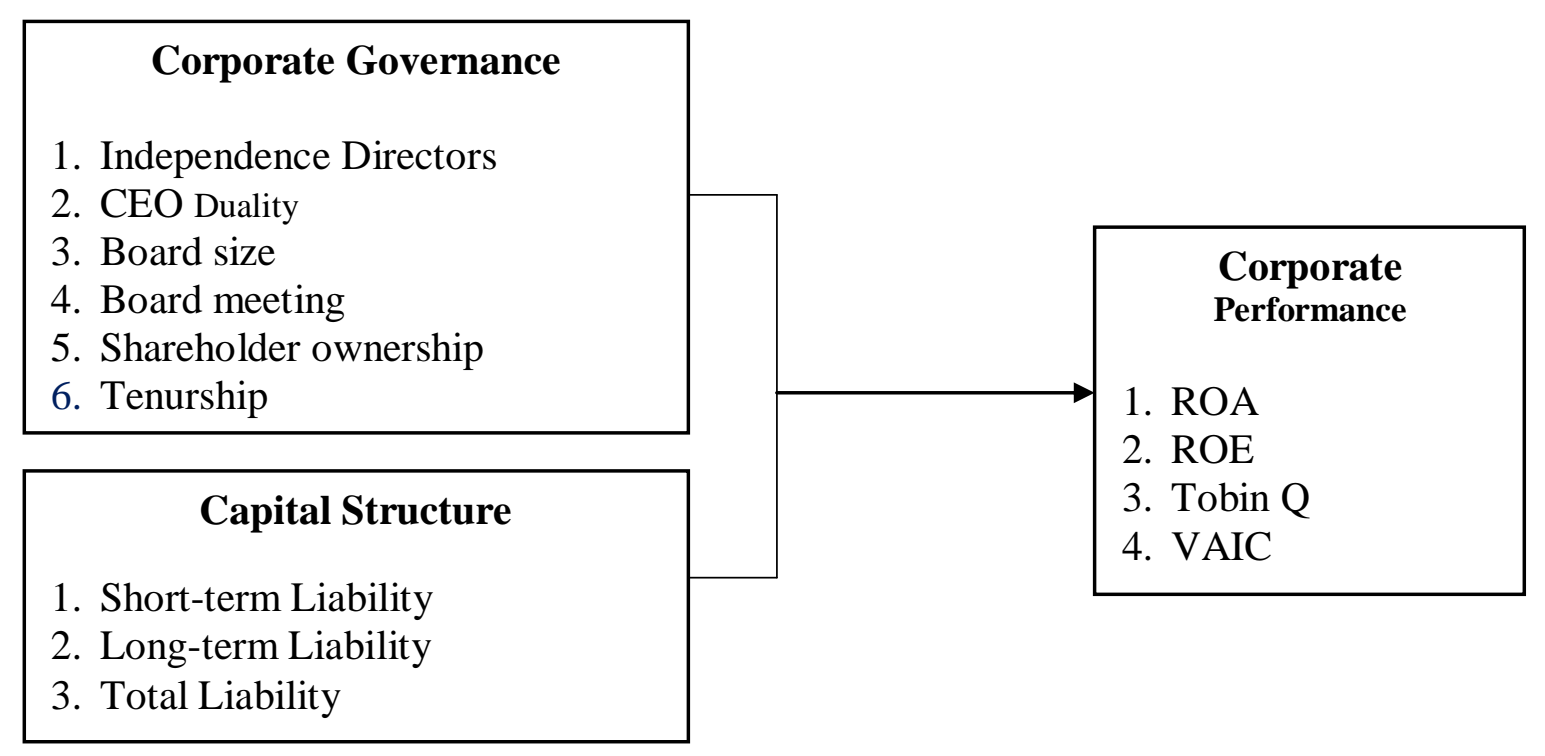

Figure 1. The Conceptual Framework of the Research

\subsection{Corporate Governance and Corporate Performance}

Good corporate governance instruments give stockholders confidence in their companies that their investment will accept satisfactory revenues (Shleifer \& Vishny, 2012). If elements of corporate governance do not exist or are not functioning properly, investors will not put their investment in the company or buy equity securities (company shares). As a result, the country's economic growth may be adversely affected as many good business opportunities are overlooked and at the same time pose financial difficulties to companies, employees and consumers (Haat et al., 2008). This shows that the destruction of stockholder assurance in Malaysia is outstanding to weak corporate governance standards in the country and lack of transparency in the financial system (Rahman et al., 2011). The failed system of a corporate governance is found to be the main factor that lead to the collapsing of several companies in Malaysia (Mohamad \& Ibrahim, 2002).

According to Ghazali (2010), the main purpose of corporate governance is to understand long-term stakeholder value and it is predictable that firms that excel in their corporate governance will stays longer in the industry compared to the companies that have a weak corporate governance structure. Haat et al, (2008) also mentioned that the general perception of corporate governance has a positive association with stable corporate performance due to the introduction of regulations by the MCCG and the listing requirements on Bursa Malaysia.

Previous researches have suggested that corporate governance has a helpful effect on company performance, and a good corporate governance is expected to boost corporate performance and increase company value (Alves \& Mendes, 2004; Chang et al., 2005). It also can be a great measure in preventing fraud (Yeh et al., 2002). Firms with improved corporate governance similarly have improved functional presentation than firms with unfortunate corporate governance (Black et al., 2006). Due to better operations, companies with better control are expected to have higher returns (Jensen \& Meckling, 1976). 
This study provides comprehensive information on how good corporate governance practices will produce a positive outcome on the performance of the company. This statement is corresponding to the agency theory that stated that good governance practices provide better supervision, protect shareholders' interests and able to improve company presentation.

Based on the arguments above, the hypothesis was developed as follows:

$\mathrm{H} 1$ : There is a positive relationship between corporate governance and corporate performance.

\subsection{Capital Structure and Corporate Performance}

Mesquita and Lara (2003) reported that the rate of repayment was definitely associated with short-term liability and equity. On the contrary, it has a counterpart to long-term liability. A long-term liability is not profitable for the company as it reduces profitability due to interest payments. While Fu (1997) found a significant association between capital structure and profitability. Furthermore, Chou and Lee (2010) reported that equity and liability repayment are strongly associated with with assets.

Similarly, Amjed (2007) revealed a strong association between luck and debt. The findings of the research also support the static trade-off theory which states that total debt has nothing to do with monetary presentation since of the distinct appearances of long-standing and short-range debt. On the other hand, the capital structure has a significant negative effect on the monetary presentation of a company (Onaolapo \& Kajola, 2010). Concurrently, Pratheepkanth (2011) reported that there is a negative association between capital structure and financial performance.

Furthermore, Ferati and Egypt (2012) found a positive association between short-term liability and financial performances and negative association between long-term liability and financial performance. Meanwhile, the positive influence of corporate capital structure on the presentation of the firm was reported by Aburub (2012). Additionally, Akhtar, Bakhsh, Ali, and Kousar (2019) found that total debt does not caused a great effect on the company's presentation. Abbas et al., (2014) reported the presence of significant negative association between liability and financial performance.

Similarly, other studies also supported that there is a positive relationship between corporate performance and capital structure, which indictae the underlying theory of capital structure (Adesina et al., 2015; Deping \& Yongsheng, 2011; Fosu, 2013). Meanwhile, the negative association between leverage and luck was reported by several research such as conducted by Chakraborty (2010), Pouraghajan et al., (2012), and Tharmila \& Arulvel (2013). In contrast, Pouraghajan et al., (2012), Kyule and Ngugi (2014), Kazempour and Aghaei (2015), Hakwani, Shahid, and Hamza (2016) reported a positive association among leverage and luck. However, Khan (2012) revealed a significant negative association between financial leverage and corporate performance.

Based on the arguments above, the hypothesis was developed as follows:

$\mathrm{H} 2$ : There is a positive relationship between capital structure and corporate performance.

\section{Conclusion}

This research proposes a conceptual framework for examining corporate governance consisting of the independent directors, CEO duality, board size, board meetings, shareholder ownership, and tenureship as well as capital structure (including short-term and long-term liability, and total liability) towards the corporate performance of public companies in Malaysia. The information provided in this study will be the foundation for future work in obtaining a more solid understanding of the impact of corporate governance and capital structure on corporate performance. Hence, it is hoped will be useful in tackling corporate performance problems in Malaysia.

\section{References}

Abbas, S. M. A., Blattner, L., De Broeck, M., ElGanainy, A. A., \& Hu, M. (2014). Sovereign debt composition in advanced economies: A historical perspective. IMF Working Papers. https://doi.org/10.5089/9781498358781.001

Abdullah, S. N. (2004). Board composition, CEO dualiti and performance among Malaysian Listed Companies. Corporate Governance, 4(4), 47-61. 
Abidin, Z. Z., Kamal, N. M., \& Jusoff, K. (2009). Board structure and corporate performance in Malaysia. International Journal of Economics and Finance, 1(1), 150-164.

Abidin, Zubaidah Zainal, Kamal, N. M., \& Jusoff, K. (2009). Board Structure and Corporate performance in Malaysia. International Journal of Economics and Finance, 1(1), 150-164. https://doi.org/10.1111/j.14678683.2005.00422.x

Abor, J. (2005). The effect of capital structure on profitability: An empirical analysis of listed firms in Ghana. The Journal of Risk Finance, 6(5), 438-445. https://doi.org/10.1108/09574090910954864

Abu-Jarad, I. Y., Yusof, N., \& Nikbin, D. (2010). A review paper on organizational culture and organizational performance. International Journal of Business and Social Science, 1(3).

Aburub, N. (2012). Capital structure and firm performance: Evidence from Palestine stock exchange. Journal of Money, Investment and Banking, 23, 109-117.

Adesina, J. B., Nwidobie, B. M., \& Adesina, O. O. (2015). Capital structure and financial performance in Nigeria. International Journal of Business and Social Research, 5(2), 21-31.

Ahmad-Zaluki, N. A., \& Wan-Hussin, W. N. (2010). Corporate governance and earnings forecasts accuracy. Asian Review of Accounting, 18(1), 50-67. https://doi.org/10.1108/13217341011046006

Ahmadpour, A., \& Yahyazadehfar, M. (2010). Financial Management (7th ed.). Leverage.

Aik Leng, A. C., \& Abu Mansor, S. (2005). Can good corporate governance practices contribute to firms' financial performance? - evidence from Malaysian companies. International Journal of Business Governance and Ethics, 1(4), 350-362.

Akhtar, A., Bakhsh, A., Ali, M., \& Kousar, S. (2019). Impact of capital structure on the performance of textilesector in Pakistan: Examining the moderating effect of liquidity. Journal of Accounting and Finance in Emerging Economies, 5(1), 1-12. https://doi.org/10.26710/jafee.v5i1.718

Akintoye, I. R. (2008). Sensitivity of performance on capital structure: A consideration for selected food and beverages companies in Nigeria. Journal of Social Sciences, Hellenic Open University, Greece, 7(1), 29-35.

Akpan, E. O., \& Amran, N. A. (2014). Board characteristics and company performance: Evidence from Nigeria. Journal of Finance and Accounting, 2(3), 81-89. https://doi.org/10.11648/j.jfa.20140203.17

Al-Ghamdi, M., \& Rhodes, M. (2015). Family ownership, corporate governance and performance: Evidence from Saudi Arabia. International Journal of Economics and Finance, 7(2), 78-89. https://doi.org/10.5539/ijef.v7n2p78

Ali, A., Ullah, A., Shah, P. Q., Shehzad, N., \& Nawab, W. (2016). Impact of capital structure on profitability: A comparative research of cement \& automobile sector of Pakistan. Journal of Managerial Sciencies, 10(1), 119130.

Alves, C., \& Mendes, V. (2004). Corporate governance policy \& company performance: The portugese case.

Amjed, S. (2007). The impact of financial structure on profitability: Research of Pakistan's Textile Sector. Management of International Business and Economic Systems, 440-450.

Ana, S., Dragan, G., \& Monica, C. (2012). Capital structure and financial performance of agricultural companies: Evidences from the Macedonian agricultural sector in transition. In European Association of Agricultural Economists 132nd Seminar.

Anum Mohd Ghazali, N. (2010). Ownership structure, corporate governance and corporate performance in Malaysia. International Journal of Commerce and Management, 20(2), $109-119$. https://doi.org/10.1108/10569211011057245

Apadore, K., Subaryani, S., \& Zainol, B. (2014). Determinants of Corporate Governance and Corporate Performance among Consumer Product Industry in Malaysia: A Theoretical Model. International Journal of Academic Research in Accounting Finance and Management Sciences, 4(2), $159-165$. https://doi.org/10.6007/IJARAFMS/v4-i2/836

Arora, A., \& Sharma, C. (2016). Corporate governance and firm performance in developing countries: Evidence from India. Corporate Governance, 16(12), 420-436.

Bahreini, M., \& Zain, M. M. (2013). Impact of corporate governance on performance of banking sector in Malaysia. Research Journal of Finance and Accounitng, 4(19), 53-63.

Basit, A., \& Hassan, Z. (2017). Impact of capital structure on firms performance: A research on Karachi Stock Exchange (KSE) listed firms in Pakistan. International Journal of Management, Accounting and Economics, 4(2), 118-135. 
Bhattarai, Y. R. (2016). Capital structure and firm performance: Evidence from Nigeria. Journal for Studies in Management and Planning, 02(03), 138-150.

Black, B. S., Jang, H., \& Kim, W. (2006). Does corporate governance predict firms' market values? Evidence from Korea. Journal of Law, Economics, and Organization, 22(2), 366-413.

Bonn, I., \& Fisher, J. (2005). Corporate governance and business ethics: Insights from the strategic planning experience. Corporate Governance: An International Review, 4(3), 730-738.

Brigham, E. F., \& Houston, J. F. (2014). Fundamentals of financial management (14th ed.). Mason, OH: Cengage Learning.

Brockington, R. (1990). Financial management. London, UK: ELBS.

Chakraborty, I. (2010). Capital structure in an emerging stock market: The case of India. Research in International Business and Finance, 24(3), 295-314. https://doi.org/10.1016/j.ribaf.2010.02.001

Chang, A., Chang, A. A. L., \& Mansor, S. (2005). Can good corporate governance practices contribute to firm's financial performance? Evidence from Malaysian companies. International Journal of Business Governance \& Ethics, 1(4), 350-362.

Chou, S. R., \& Lee, C. H. (2010). The research on the effects of capital structure on firm performance \& evidence from the nonfinancial industry of Taiwan 50 \&Taiwan Mid-cap 100 from 1987 to 2007. Journal of Statistics \& Management Systems, 13(5), 1069-1078.

Coles, J. W., McWilliams, V. B., \& Sen, N. (2001). An examination of the relationship of governance mechanisms to performance. Journal of Management, 27(1), 23-50.

Dehaene, A., Vuyst, V. D., \& Ooghe, H. (2001). Corporate performance and board structure in Belgian companies. Long Range Planning, 34, 383-398.

Denis, D. K., \& McConnell, J. J. (2003). International corporate governance. Journal of Financial and Quantitative Analysis, 38, 1-36.

Deping, C., \& Yongsheng, C. (2011). The relationship research between the corporate performance, ownership concentration and equity balance degree: Empirical studies of small and medium-sized enterprise from 2007 to 2009. Journal of Accounting Research, 1, 38-43.

Ferati, R., \& Ejupi, E. (2012). Capital stucture and profitbility: The Macedonian case. European Scientific Journal, 8(7), 51-58. https://doi.org/10.1016/j.jbankfin.2008.07.019

Fosu, S. (2013). Capital structure, product market competition and firm performance: Evidence from South Africa. Quarterly Review of Economics and Finance, 53, 140-151. https://doi.org/10.1016/j.qref.2013.02.004

$\mathrm{Fu}, \mathrm{C}$. A. (1997). Relationship between capital structure \& profitability: A time-series cross-sectional research on Malaysian firms. PhD dissertation, Universiti Utara Malaysia.

Ghazali, N. A. M. (2010). Ownership structure, corporate governance and corporate performance in Malaysia. International Journal of Commerce and Management, 20(2), $109-119$. https://doi.org/10.1108/10569211011057245

Gleason, K. C., Mathur, L. K., \& Mathur, I. (2000). The interrelationship between culture, capital structure, and performance: Evidence from European Retailers. Journal of Business Research, 50(2), 185-191.

Goyal, A. M. (2013). Impact of capital structure on performance of listed public sector banks in India. International Journal of Business and Management Invention, 2(10), 35-43.

Haat, M. C., Raaman, H. R., \& Mahenthiran, S. (2008). Corporate governance, transparency and performance of Malaysian companies. Managerial Auditing Journal, 23(8), 744 - 778.

Haji, A. A. (2014). The relationship between corporate governance attributes and firm performance before and after the revised code: Some Malaysian evidence. International Journal of Commerce and Management, 24(2), 134151. https://doi.org/10.1108/17465681011017255

Hakwani, M. S., Shahid, M. S., \& Hamza, A. (2016). Effect of corporate governance and financial leverage on market value added in Pakistan. Journal of Accounting and Finance in Emerging Economies, 2(1), 17-26. https://doi.org/10.26710/jafee.v2i1.49

Haniffa, R., \& Hudaib, M. (2006). Corporate governance structure and performance of Malaysian listed companies. Journal of Business Finance \& Accounting, 33(7\&8), 1034-1062. https://doi.org/10.1111/j.14685957.2006.00594.x

Hermalin, B. E. (2005). Trends in Corporate Governance. The Journal of Finance, LX(5), 2351-2384. https://doi.org/10.1111/j.1540-6261.2005.00801.x 
Hooley, G., Greenley, G., Fahy, J., \& Cadogan, J. (2001). Market-focused resources, competitive positioning and firm performance. Journal of Marketing Management, 17(5-6), 503-520.

Jaffar, R., \& Abdul-Shukor, Z. (2016). The role of monitoring mechanisms towards company's performance. Journal of Accounting in Emerging Economies, 6(4), 408-428. https://doi.org/10.1108/JAEE-05-2014-0021

Jensen, M. C., \& Meckling, W. H. (1976). Theory of the firm: Managerial behavior, agency costs and ownership structure. Journal of Financial Economics, 3(4), 305-360.

Johl, S. K., Kaur, S., \& Cooper, B. J. (2015). Board characteristics and firm performance: Evidence from Malaysian public listed firms. Journal of Economics, Business and Management, 3(2), $239-243$. https://doi.org/10.7763/JOEBM.2015.V3.187

Kazempour, M., \& Aghaei, M. A. (2015). Capital structure and firms performance: Evidence from Tehran stock exchange. International Journal of Management, Accounting and Economics, 2(2), $149-152$. https://doi.org/10.5539/ijef.v7n12p1

Khan, A. G. (2012). The relationship of capital structure decisions with firm performance: A research of the engineering sector of Pakistan. International Journal of Accounting and Financial Reporting, 2(1), $245-262$. https://doi.org/10.5296/ijafr.v2i1.1825

King, M., \& Santor, E. (2008). Family values: Ownership structure, performance and capital structure of Canadian firms. Journal of Banking and Finance, 32(11), 2423-2432.

Kod Tadbir Urus Korporat Malaysia. (2011). Corporate covernance blueprint 2011: Towards excellence in corporate governance. Bukit Kiara, Kuala Lumpur: Suruhanjaya Sekuriti Malaysia.

Kod Tadbir Urus Korporat Malaysia. (2012). Malaysian Code on Corporate Governance 2012. https://doi.org/10.1007/s13398-014-0173-7.2

Koufopoulos, D., Zoumbos, V., Argyropoulou, M., \& Motwani, J. (2008). Top management team and corporate performance: A research of Greek firms. Team Performance Management: An International Journal, 14(7/8), 340-363. https://doi.org/http://dx.doi.org/10.1108/13527590810883415

Kyule, C. M., \& Ngugi, K. (2014). Influence of capital structure on leverage of small and medium size enterprises in Kenya. European Journal of Business Management, 1(11), 1-22.

Lashgari, M. (2004). Corporate governance: Theory and practice. Journal of American Academy of Business, 5, 4651.

Leng, ACA \& Mansor, S. A. (2005). Can good corporate governance practices contribute to firm's financial performance? Evidence from Malayisan companies. International Journal of Business Governance \& Ethics, 1(4), 350-362.

Lind, P., Sepulveda, E., \& Nunez, J. (2000). On the applicability of a computer model for business performance analysis in SMEs: a case research from Chile. Information Technology for Development, 9(1), 33-44.

Madrid-Guijarro, A., Auken, H. Van, \& García-Pérez-de-Lema, D. (2007). An analysis of factors impacting performance of Spanish manufacturing firms. Journal of Small Business and Entrepreneurship, 20(4), 369-386. https://doi.org/10.1080/08276331.2007.10593406

Malaysia Kini. (2016). Selain PKFZ, 9 lagi kes rasuah gagal dipertangungjawabkan. Malaysia Kini.

Malaysia Today. (2010). Sime Darby=Renong II? MEB bakal ulangi kegagalan zaman Mahathir. Malaysia Today.

Margaritis, D., \& Psillaki, M. (2010). Capital structure, equity ownership and firm performance. Journal of Banking \& Finance, 34, 621-632.

Maury, B. (2006). Corporate governance \& Top executives,.

Mesquita, J. M. C. de, \& Lara, J. E. (2003). Capital structure and profitability: The Brazilian case.

Mohamad, A. A., \& Ibrahim, M. K. (2002). Determinant of firm level governance: The evidence Malaysian corporate governance. International Journal of Business \& Society, 7(5).

MSWG. (2017). Key corporate governance statistics of public listed companies in Malaysia.

Mustapha, M., \& Ahmad, A. C. (2011). Agency theory and managerial ownership: Evidence from Malaysia. Managerial Auditing Journal, 26(5), 419-436.

Najmi, M., Rigas, J., \& Fan, I. (2005). A framework to review performance measurement systems. Business Process Management Journal, 11(2), 109-122. https://doi.org/10.1108/14637150510591129

Omnamasivaya, B., \& Prasad, M. S. V. (2017). Does financial performance really improve the environmental accounting disclosure practices in India: An empirical evidence from nifty companies. African J. of Economic and Sustainable Development, 6(1), 52. https://doi.org/10.1504/AJESD.2017.082801 
Onaolapo, A. A., \& Kajola, S. O. (2010). Capital structure \& firm performance: Evidence from Nigeria. European Journal of Economics, Finance \& Administrative Sciences, 25, 70-82.

Ong, T. S., Heng, T. B., Ahmad, N., \& Muhamad, H. (2015). Relation between corporate governance attributes and financial performance in oil and gas industries. Institutions and Economies, 7(2), 56-84.

Parker, C. (2000). Performance measurement. Work Research, 49(2), 63-66.

Patel, B. S., Booker, L. D., Ramos, H. M., \& Bart, C. (2015). Mission statements and performance in non-profit organisations. Corporate Governance, 15(5), 759-774. https://doi.org/10.1108/CG-07-2015-0098

Ponnu, C. H. (2008). Corporate governance structures and the performance of Malaysian Public Listed Companies. International Review of Business Research Papers, 4(2), 217-230.

Pouraghajan, A., Ail, N., Tabari, Y., Ramezani, A., Mansourinia, E., Emamgholipour, M., \& Majd, P. (2012). Relationship between cost of capital and accounting criteria of corporate performance evaluation: Evidence from Tehran Stock Exchange. World Applied Sciences Journal, 20(5), 666-673. https://doi.org/10.5829/idosi.wasj.2012.20.05.2368

Pratheepkanth, P. (2011). Capital structure and financial performance: Evidence from selected business companies in Colombo Stock Exchange Sri Lanka. Journal of Arts, Science \& Commerce, 2(2), 171-181.

Rahman, A., Ku Ismail, K. N., \& Nordin, W. W. H. (2011). The influence of corporate governance and firms's characteristics o $\mathrm{n}$ the extent of compliance with MASB standards among Malaysian listed companies. International Journal of Business \& Social Research, 1(1), 153-173.

Runhui, L., Jianhong, F., Yang, Z., Hongjuan, Z., \& Rujing, H. (2011). Research on the relationship among corporate governance environment, governance behavior and governance performance: Evidences from the evolution of Chinese telecommunication industry. Nankai Business Review International, 2(4), 358 - 382.

Saad, N. M. (2010). Corporate governance compliance and the effects to capital structure in Malaysia. International Journal of Economics and Finance, 2(1), 105-114. https://doi.org/10.1016/S2214-398X(14)00010-7

Salim, M., \& Yadav, R. (2012). Capital structure and firm performance: Evidence from Malaysian Listed Companies. Procedia - Social and Behavioral Sciences, 65(ICIBSoS), 156-166. https://doi.org/10.1016/j.sbspro.2012.11.105

San, O. T., \& Heng, B. (2011). Capital structure and corporate performance of Malaysian construction sector. International Journal of Humanities and Social Science, 1(2), 28-36.

Sanda, A., Mikailu, A. S., \& Garba, T. (2005). Corporate governance mechanisms \& firm financial performance in Nigeria. AERC Research Paper, Nairobi, 149.

Shleifer, A., \& Vishny, R. W. (2012). A survey of corporate governance. Journal of Finance, 52(2), 737-783.

Sinesilassie, E. G., Tabish, S. Z. S., \& Jha, K. N. (2017). Critical factors affecting cost performance: A case of Ethiopian public construction projects. International Journal of Construction Management, 3599(February), 112. https://doi.org/10.1080/15623599.2016.1277058

Tharmila, K., \& Arulvel, K. K. (2013). The impact of the capital structure and financial performance: A research of the listed companies traded in Colombo stock exchange. Merit Research Journal of Accounting, Auditing, Economics and Finance, 1(5), 106-117.

Uadiale, O. M. (2010). The impact of board structure on corporate financial performance in Nigeria. International Journal of Business and Management, 5(10).

Utaranews. (2017). Perwaja rugi RM15 bilion, Mahathir mahu proton jadi senasib macam perwaja? Utaranews.

Vătavu, S. (2015). The impact of capital structure on financial performance in Romanian Listed Companies. Procedia Economics and Finance, 32(15), 1314-1322. https://doi.org/10.1016/S2212-5671(15)01508-7

Xu, Y., \& Qiu, A. (2012). A survey of corporate governance: Internal trends \& China made. Nankar Business Review International, 3(1), 4-30.

Yeh, Y. H., Lee, T. S., \& Ko, C. (2002). Corporate governance and rating system. SUNBRIGHT Publishers.

Zeitun, R., \& Tian, G. G. (2014). Capital Structure and Corporate Performance: Evidence from Jordan. SSRN Electronic Journal. https://doi.org/10.2139/ssrn.2496174 